Article

\title{
Experimental Study on a Passive Fuel Cell/Battery Hybrid Power System
}

\section{Yong-Song Chen *, Sheng-Miao Lin and Boe-Shong Hong}

Advanced Institute of Manufacturing with High-Tech Innovation and Department of Mechanical Engineering, National Chung Cheng University, 168, University Rd., Minhsiung Township, Chiayi 62102, Taiwan; E-Mails: bruce760916@hotmail.com.tw (S.-M.L.); imehbs@ccu.edu.tw (B.-S.H.)

* Author to whom correspondence should be addressed; E-Mail: imeysc@ccu.edu.tw; Tel.: +886-5-2720411 (ext. 333309); Fax: +886-5-2720589.

Received: 18 October 2013; in revised form: 22 November 2013 / Accepted: 3 December 2013 / Published: 10 December 2013

\begin{abstract}
A laboratory-scale passive hybrid power system for transportation applications is constructed and tested in this study. The hybrid power system consists of a fuel cell stack connected with a diode, a lithium-ion battery pack connected with a DC/DC power converter and another diode. The power converter is employed to regulate the output voltage of the battery pack. The dynamic responses of current and voltage of the stack to the start-up and acceleration of the load are experimentally investigated at two different selected output voltages of the DC/DC converter in the battery line. The power sharing of each power source and efficiency are also analyzed and discussed. Experimental results show that the battery can compensate for the shortage of supplied power for the load demand during the start-up and acceleration. The lowest operating voltage of the fuel cell stack is limited by the regulated output voltage of the DC/DC converter. The major power loss in the hybrid power system is attributed to the diodes. The power train efficiency can be improved by lowering the ratio of forward voltage drop of the diode to the operating voltage of the fuel cell stack.
\end{abstract}

Keywords: hybrid power system; fuel cell; lithium-ion battery; power converter; power train efficiency 


\section{Introduction}

Proton exchange membrane fuel cells (PEMFCs) are considered as one of potential power sources for transportation applications in the near future. However, the dynamic response of a PEMFC to a step-increase in power demand is relatively slow and designed nominal power usually cannot meet the instantaneous requirements during start-up or acceleration. On the contrary, lithium-ion batteries (LIBs) have the advantages of quick response and large C-rate discharging. The performance of a PEMFC can be improved when it is hybridized with secondary batteries.

There are two types of fuel cell/battery hybrid power systems: active and passive systems. In an active power system, a DC/DC converter is installed between the fuel cell and the battery. The converter adjusts the voltage of each power source to the bus voltage and manages the power sharing between each source [1-3]. Gao et al. [1] experimentally compared two active hybrid power systems with different battery sizes in terms of specific power, power density, volume, and weight. Blackwelder et al. [2] designed a controller to manage the power output from fuel cells and LIBs in an active hybrid power system. In their control strategy, the fuel cell could provide the maximum power to the load before any power was drawn from the battery. Jiang et al. [3] developed different control strategies in which the fuel cell current was limited in safe values while regulating the charging current and voltage of the battery. Moore et al. [4] and Zhou et al. [5] simulated fuel cell vehicles with different configurations. Zhou concluded that the best approach for hybridization of the power train was to use supercapacitors with load leveled control.

Thounthong et al. [6] designed an active hybrid power system that consists of a fuel cell stack, a battery module, and a supercapacitor module. Each of these power sources was connected with a DC/DC converter. A control algorithm was developed to manage power sharing from these power sources. Tang et al. [7] developed an active hybrid system with a fuel cell stack and a lead-acid battery for a lightweight vehicle. Büchi et al. [8] designed and tested a light-weight fuel cell vehicle with an active hybrid power system. A central controller was required in their systems to manage the power output of the stack for hybridization.

For the passive hybrid system, the DC/DC converter may be installed in the fuel cell line or the battery line without control [9]. However, the output voltage of the DC/DC converter needs to be carefully determined according to the characteristics of both power sources. Aso et al. [10] showed a passive hybrid configuration developed by Toyota Motor Corporation; however, the dynamic behavior of each power source was not reported. Bernard et al. [11] developed a model to simulate a passive hybrid power system with an $\mathrm{H}_{2} / \mathrm{O}_{2}$ fuel cell system. The power sharing in their model was achieved by adjusting the fuel cell operating pressure. The analysis results showed that this approach could satisfy the power demand of the load while sustaining the state of charge of the battery. Keränen et al. [12] built a triple-hybrid power system comprising a fuel cell system, an ultracapacitor module, and a lead-acid battery pack for an electric forklift. Their study showed that hybridization with the battery or capacitor could reduce the variation of the fuel cell and meet all power requirements.

In summary, compared with active hybrid power systems, passive hybrid power systems have the advantages of simpler configuration and higher efficiency since a DC/DC converter at the fuel cell output is saved; however, in a passive system, the power sharing between the fuel cell and the battery cannot be precisely controlled. 
Recently, Nishizawa et al. [13] developed a passive direct hybridization system using a fuel cell and a battery. There was no DC/DC converter in their system. Although, this direct hybridization was demonstrated to quickly response to the dynamic load variations, the fuel cell voltage gradually decreased with the voltage of the battery during discharging. The fuel cell could be operated at a low efficiency point if the battery continuously discharged.

In this work, a passive hybrid system is designed for transportation applications, in which a DC/DC converter is installed in the battery line to fix the output voltage of the LIB. The effect of regulated voltage on the system is investigated. The dynamic responses of the fuel cell and the battery with respect to the load variations are studied during the start-up and acceleration of the load.

\section{Experimental}

\subsection{Hybrid System Design}

The passive hybrid power system in this study is designed for transportation applications. The fuel cell stack is the major power source in this hybrid system and it meets the rated power consumption of the load. The secondary battery pack only provides supports for a sudden power demand during start up and acceleration. Under the above consideration, the hybrid power system design in this work is depicted in Figure 1. A major difference between this work and other published hybrid systems is the $\mathrm{DC} / \mathrm{DC}$ converter installed in the battery pack line. In a direct hybridization system without a $\mathrm{DC} / \mathrm{DC}$ converter, the voltage of fuel cell will follow that of batteries since the battery voltage gradually decreases during discharge. The DC/DC converter is employed to fix the output voltage of the LIB so that the fuel cell stack will not be operated at any voltage lower than the designed voltage.

Figure 1. A schematic of the experimental setup of the fuel cell/battery hybrid power system.

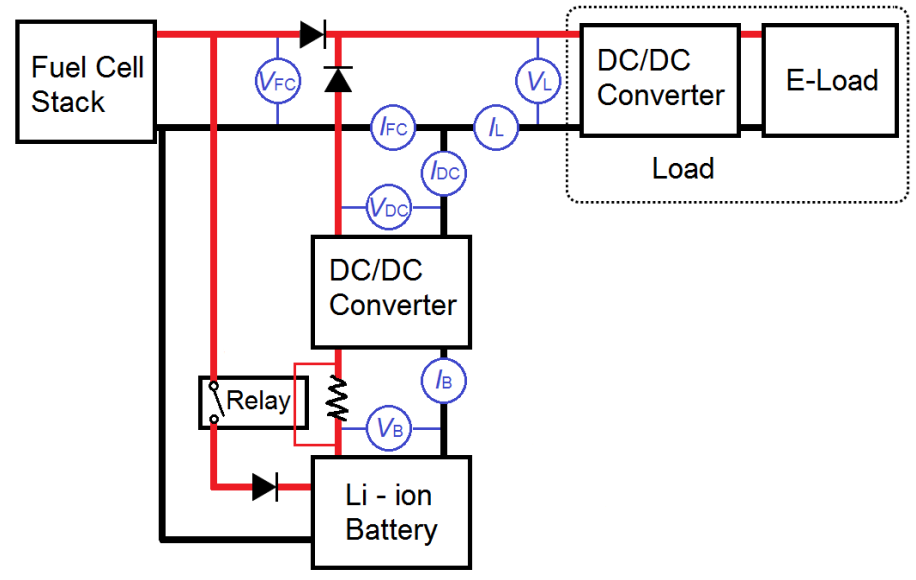

In this experiment, the fuel cell stack (H-30, Horizon, Chicago, IL, USA) consisted of 14 cells and provided a rated power of $30 \mathrm{~W}$. Two lithium-ion batteries (LYS-187365S, LynoPower, Taoyuan, Taiwan) were connected in series as a pack. A DC/DC boost converter (LM2577, Current Logic, Shenzhen, China) was connected with the battery to regulate the voltage of the battery line. A diode was installed to prevent the battery pack from charging through the output line. The battery charging function was designed through another line, where a relay was installed to manage the charging circuit. Normally, the battery was in the charging mode. A current output signal from the battery pack to the 
load would open the charging circuit and the battery pack became as discharging mode. The load consisted of a DC/DC converter module (PSD-30A-24, Meanwell, Taipei, Taiwan) and an electronic load (PLZ664WA, Kikusui Electronics, Yokohama, Japan) to simulate power demands during the start-up and acceleration. Note: certain commercial instruments or materials used in this work do not imply recommendation or endorsement by the authors or the university.

\subsection{Experimental Procedure}

The as-purchased fuel cell stack, H-30, was originally embedded with a controller, which managed the anode purge and the cathode air supply. However, due to its built-in intermittent shortcut function, the voltage of the stack fluctuated frequently when the stack was operated at a constant-current mode. Therefore, we decided to remove the controller and the purge valve at the anode outlet. As a result, the fuel cell stack was operated in anodic open-ended mode. During the experiment, the hydrogen was fed at a constant flow rate with a stoichiometric ratio of 1.2 with respect to the rated current 3.6 A.

The output voltage $\left(V_{\mathrm{DC}}\right)$ of the $\mathrm{DC} / \mathrm{DC}$ converter in the LIB line was a key factor that influenced the operating point of the fuel cell stack. Two tests were performed with $V_{\mathrm{DC}}$ of $9 \mathrm{~V}$ and $10 \mathrm{~V}$. Since the fuel cell stack and the LIB pack were connected with a diode, respectively, the forward voltage drops of these two lines were close.

In each test, the current of electronic load was controlled to simulate power demand during the start-up and acceleration. In the experiment, voltages and currents of the fuel cell stack $\left(V_{\mathrm{FC}}\right.$ and $\left.I_{\mathrm{FC}}\right)$, the LIB pack $\left(V_{\mathrm{B}}\right.$ and $\left.I_{\mathrm{B}}\right)$, the DC/DC converter $\left(V_{\mathrm{DC}}\right.$ and $\left.I_{\mathrm{DC}}\right)$, and the load $\left(V_{\mathrm{L}}\right.$ and $\left.I_{\mathrm{L}}\right)$ were recorded. The installed sensor positions are shown in Figure 1.

\section{Results and Discussion}

\subsection{Performances of Power Sources}

The aim of the work is to investigate the dynamic response of each power source to the variation of load power. The charging behavior of the battery pack is also presented in this study. Figure 2a shows the performance curve of the fuel cell stack. The overall stack performance measured in this study is lower than that provided by its manufacturer. The main reason is that in this study the supplied hydrogen was not humidified, resulting in lower membrane conductivity. Besides, the cathode air flow rate is kept constant regardless of the operating current density. According to the polarization curve, we chose $9 \mathrm{~V}$ as the lowest operating limit in order to keep stack efficiency higher than 50\% (lower heating value, LHV). Figure $2 b$ shows the voltage variation of the LIB discharging at different $\mathrm{C}$-rates. As expected, the higher the discharging current, the lower the battery voltage. Since the voltage of battery line varies with time and output current, a DC/DC converter is required to fix the voltage in this line. 
Figure 2. (a) Performance curve of the fuel cell stack; and (b) voltage variations of the lithium-ion battery (LIB) pack discharging at different C-rates.

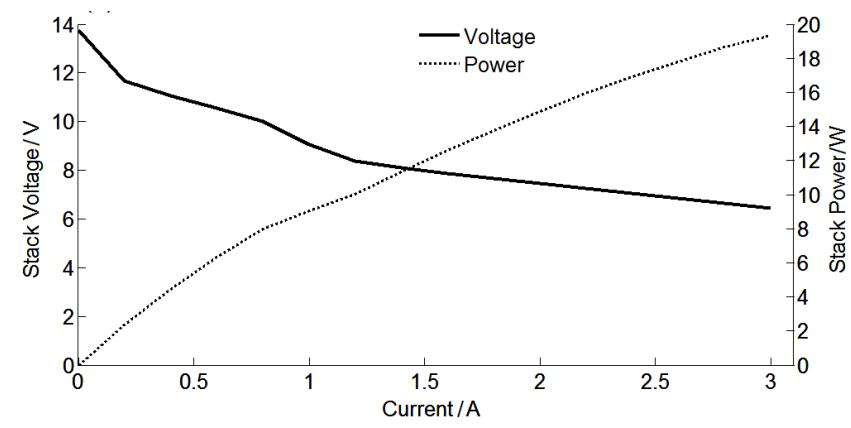

(a)

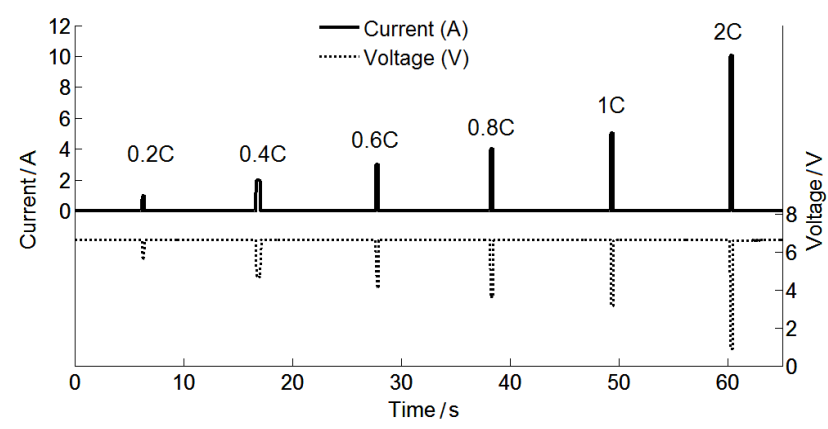

(b)

\subsection{Dynamic Response of the Hybrid Power System}

Figure 3 presents variations of currents and voltages of the two power sources and the load when the output voltage of the DC/DC converter in the LIB line is adjusted to $9 \mathrm{~V}$. It clearly shows the addition of currents provided by the two power sources is equal to the load current. Within the initial $14 \mathrm{~s}$, the load consumes approximately a current of $0.2 \mathrm{~A}$. The consumption is attributed to the DC/DC converter within the load since there is a minimum power requirement for the converter. After $14 \mathrm{~s}$, when the start-up peak current is $2.2 \mathrm{~A}$, the fuel cell stack can quickly supply a current of $2 \mathrm{~A}$ for a short duration $0.05 \mathrm{~s}$. At this moment, its voltage drops to around $9 \mathrm{~V}$, which is almost equal to the output voltage of the LIB line. Then the LIB compensates for the shortages of current for the load demand. After the 2.2-A peak, the load current decreases to $0.5 \mathrm{~A}$. The fuel cell can support for this load demand and its voltage increases to $11 \mathrm{~V}$, which is higher than that of LIB line; thus, LIB provides no power. The current peaks at $24 \mathrm{~s}$ and $34.5 \mathrm{~s}$ are simulations for the acceleration of load demand. Because of the slow response of fuel cell stack to the current change, LIB provides part of current for the load requirement.

Figure 3. Dynamic responses of the hybrid power system at $V_{\mathrm{DC}}=9 \mathrm{~V}$.

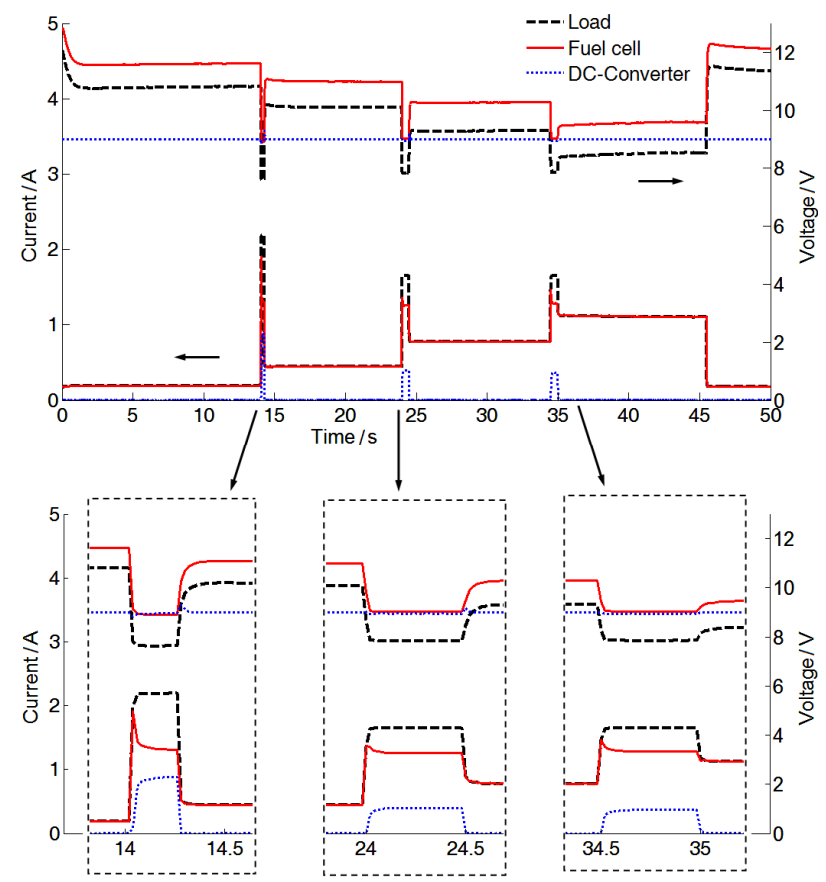


Figure 3 also shows the voltage variations of the load, the fuel cell stack, and the DC-DC converter in the LIB line. The voltage of the DC/DC converter shows a little fluctuation when the LIB provides current. During the peak load current, the voltage of the fuel cell stack drops to a limit of roughly $9 \mathrm{~V}$. This value is affected by the forward voltage drop of diodes installed in the two power lines. Accordingly, measured load voltage is approximately $0.8 \mathrm{~V}$ lower than fuel cell voltage.

When the voltage of the DC/DC converter in the LIB line is increased to $10 \mathrm{~V}$, the transient response of the hybrid system is presented in Figure 4. Similar to the results shown in Figure 3, LIB supports for part of the peak current demand when the voltage of the fuel cell stack decreases to around $10 \mathrm{~V}$, which is equal to the voltage of the DC/DC converter in the LIB line. After $34 \mathrm{~s}$, since the load level exceeds the maximum power of the fuel cell stack operating at $10 \mathrm{~V}$, LIB starts to provide current. Compared with Nishizawa's design without a DC/DC converter, this hybrid configuration helps stabilize the voltage of fuel cell stack when both power sources provide current.

Figure 4. Dynamic responses of the hybrid power system at $V_{\mathrm{DC}}=10 \mathrm{~V}$.

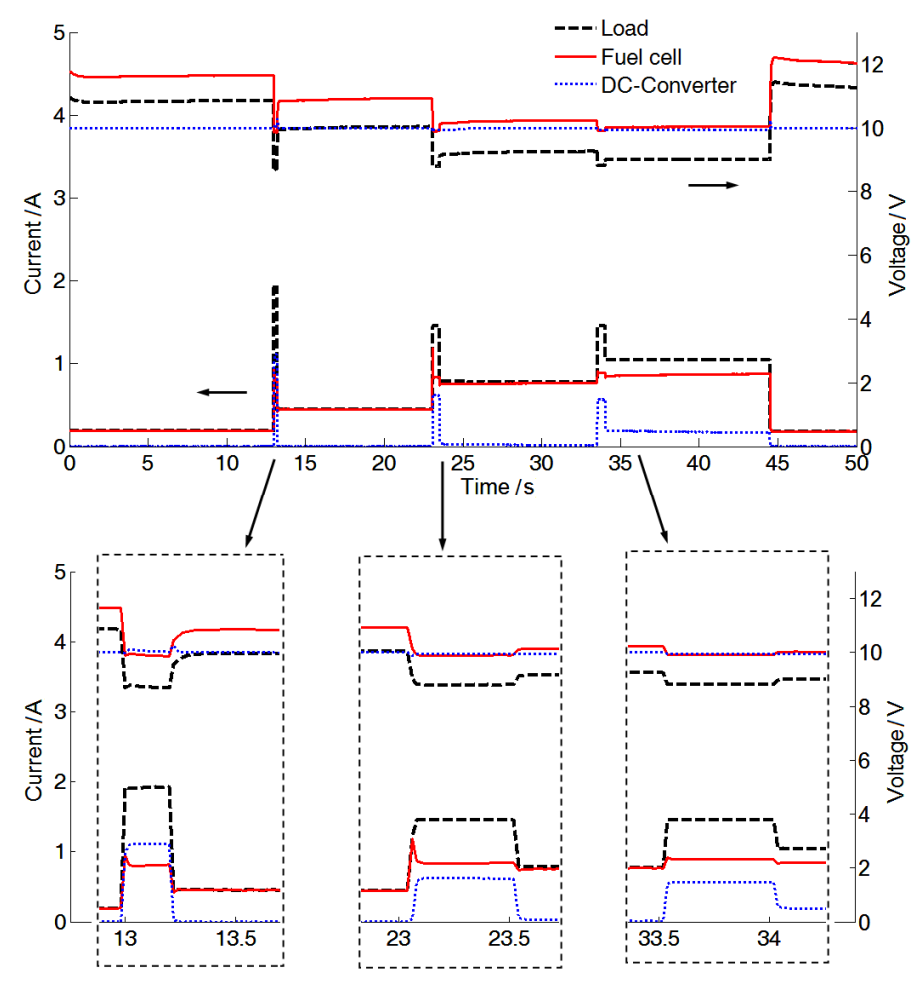

\subsection{Analysis of Power Train Efficiency}

Figure 5 shows power sharing and power train efficiency of the hybrid system with the DC/DC converter at $9 \mathrm{~V}$. The supplied power (black dotted line) is the overall power provided by the fuel cell stack and the LIB pack. The consumed power (red solid line) is measured at the load side. The difference between the supplied and the consumed powers is the power loss due to the diodes and the DC/DC converter in the LIB line. The power train efficiency in Figure 5 is defined as the ratio of consumed power to supplied power. It is shown that the efficiency is around 0.9 when the fuel cell stack provides power alone and the efficiency depends on its operating voltage. During the peak power demand, the efficiency is approximately between 0.8 and 0.83 . When LIB provides power, the connected $\mathrm{DC} / \mathrm{DC}$ converter consumes a portion of power, resulting in lower efficiency. 
Figure 5. Power sharing of each power source and efficiency of the hybrid power system at $V_{\mathrm{DC}}=9 \mathrm{~V}$.

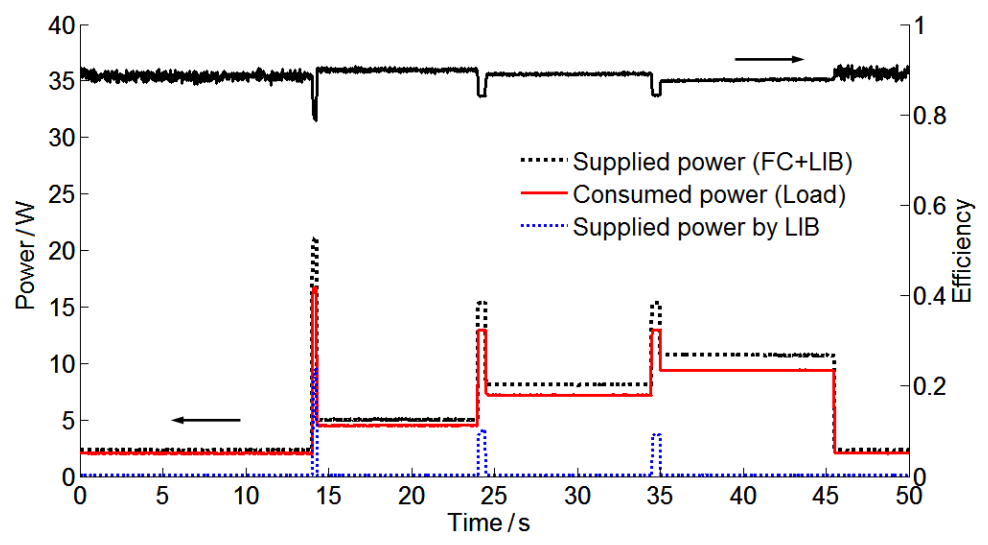

Figure 6 shows the power sharing and power train efficiency of the system when the output voltage of the $\mathrm{DC} / \mathrm{DC}$ converter is $10 \mathrm{~V}$. The results are similar to that of the $9-\mathrm{V}$ system shown in Figure 5. In Figure 6, when only the fuel cell stack supports for the load demand, the efficiency is 0.9 . When the LIB provides current, the connected DC/DC converter and diode have significant influence on the efficiency of the hybrid power system. For the peak at $13 \mathrm{~s}$, the system efficiency is 0.66 . The configuration in this study is aimed for transportation applications, in which the fuel cell stack supports for nominal power demand and LIB compensates for sudden power demand during the start-up and acceleration. Accordingly, the efficiency of the fuel cell line is the major concern in this study.

Figure 6. Power sharing of each power source and efficiency of the hybrid power system at $V_{\mathrm{DC}}=10 \mathrm{~V}$.

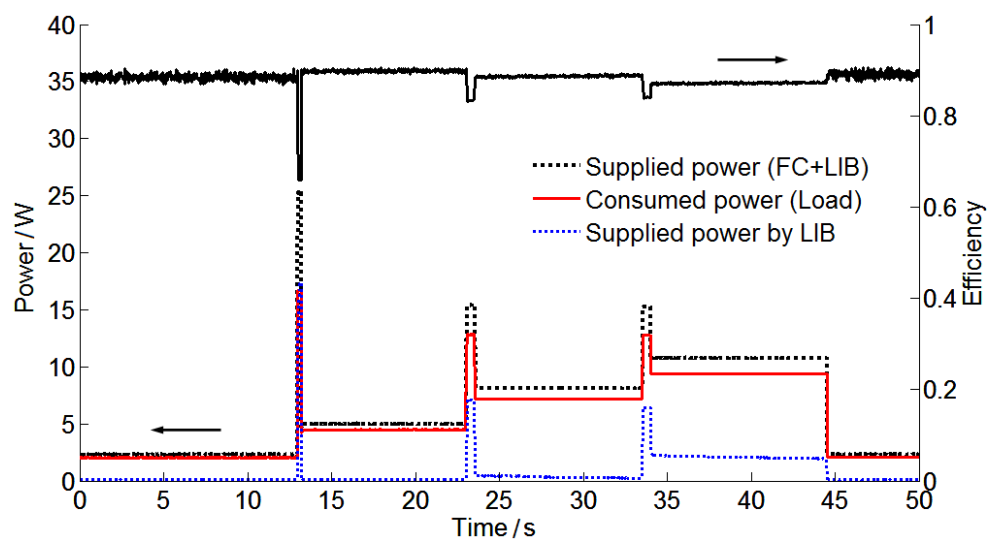

Since the voltage of the fuel cell stack in this study varies from $9 \mathrm{~V}$ to $12 \mathrm{~V}$, the forward voltage drop of the connected diode has a significant effect on the efficiency. The power train efficiency can be estimated as:

$$
\varepsilon=1-\frac{\text { forward voltage drop of the diode }}{\text { operating voltage of the fuel cell stack }}
$$

If a hybrid power system employs a fuel cell stack with an operating voltage higher than $24 \mathrm{~V}$ and a diode with a lower forward voltage drop (e.g., a Schottky diode with a voltage drop of $0.45 \mathrm{~V}$ ), its efficiency can be increased to approximately 0.98 . 


\subsection{Charging Characteristics}

The recharging function is an important issue in the passive hybrid system. In this study, the LIB is recharged through another circuit, as shown in Figure 1. A normally-closed relay is installed in the charging loop. Thus, at a low power demand, the fuel cell provides power for the load and charges the LIB simultaneously, as shown in Figure 7. At the 10, 20 and 30 s points, when the LIB provides power for the load, the bypassed current actives the normally-closed relay circuit to stop charging. Accordingly, the LIB is either in charging or discharging mode. In the future, a battery charger will be installed in the charging loop to monitor the status of the LIB for safety purposes.

Figure 7. Demonstration of the charging behavior of the passive hybrid system. The LIB is either in charging or discharging mode.

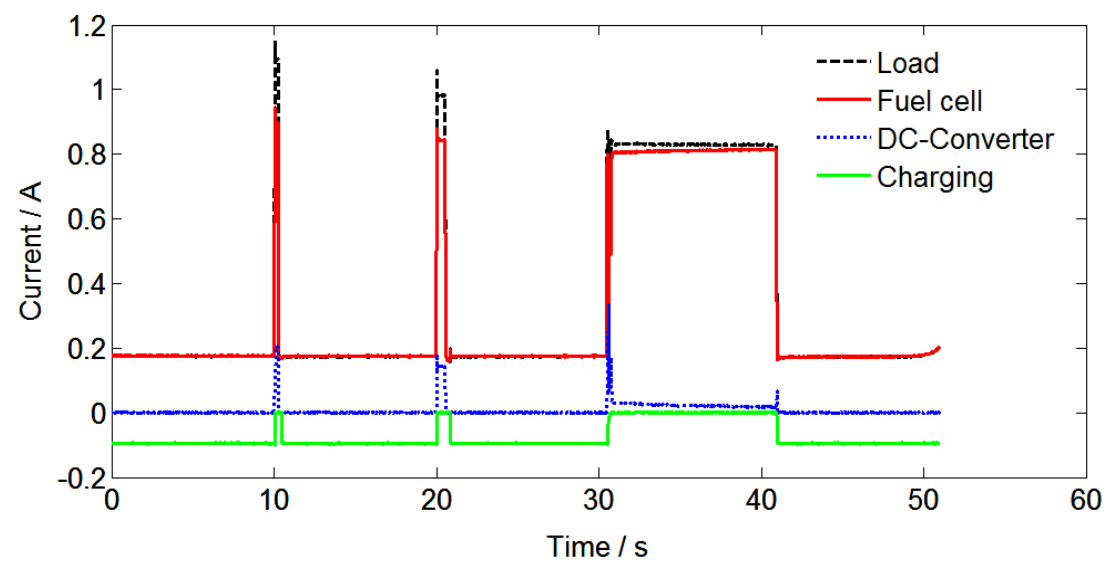

\subsection{Design Procedure for the Hybrid Power System}

In the final section, a procedure is proposed for designing a passive hybrid power system. For the passive hybrid configuration, the lowest limit of the fuel cell voltage is one of the most important parameters that should be predetermined. In a fuel cell electric vehicle, the maximum power of the fuel cell is designed to support the nominal power requirement, whereas the LIB is for start-up and acceleration. The following procedure is proposed to size the fuel cell and the LIB:

(1) Select the lowest limit of operating voltage, at which the fuel cell can satisfy the maximum continuous power requirement;

(2) Determine the cell number and the active area according to Equation (1);

(3) The output voltage of the DC/DC converter in the LIB line is adjusted to be the same with the lowest limit of the fuel cell voltage;

(4) Measure the peak power demand during start-up and acceleration and then determine the capacity of the LIB.

Although the power scale in this study is miniature when compared with that in real transportation applications, this study demonstrates the feasibility of the passive fuel cell/battery hybrid power system. So far, passive hybrid systems using 10-kW fuel cell stacks have been studied by Bernard [11] and Nishizawa [13]. Aso [10] showed a schematic of the passive hybrid system. Their studies presented the possibility of the passive hybrid configuration. However, we need more 
study and experiments to prove the feasibility of the passive hybrid system to be used for real transportation applications in the power level of at least $30 \mathrm{~kW}$.

\section{Conclusions}

In present study, a passive fuel cell and battery hybrid power system for transportation applications are developed. The fuel cell line is designed as the main power source, while the battery line is for start-up and acceleration. In order to regulate the output voltage of the LIB, a DC/DC converter is connected in the battery line. A diode is connected with each power source for protection. The load current is controlled to simulate the power demand during start-up and acceleration. The currents and voltages for each power source and load were measured and analyzed at two different selected regulation voltages in the battery line. The following conclusions can be drawn from this experiment:

(1) During start-up and acceleration, the fuel cell stack cannot support the peak power demand. When the voltage of the fuel cell stack drops to the regulated LIB voltage, the battery compensates for the shortage of power.

(2) The maximum power supply of the fuel cell stack can be determined by the output voltage of the LIB line. With the DC/DC converter in the LIB line, the lowest operating voltage of the fuel cell stack is constrained.

(3) For a light duty vehicle, the major power loss source in this hybrid power system is the diodes. Choosing a low ratio of forward voltage drop to fuel cell voltage will improve the power train efficiency; however, for a high voltage system, the diode voltage drop is a minor issue.

(4) A battery management system is required to monitor the state of health of the LIB for safety.

\section{Acknowledgments}

The authors would like to acknowledge the financial support provided to this study by the Ministry of Education of Taiwan.

\section{Conflicts of Interest}

The authors declare no conflict of interest.

\section{References}

1. Gao, L.; Jiang, Z.; Dougal, R.A. An actively controlled fuel cell/battery hybrid to meet pulsed power demands. J. Power Sources 2004, 130, 202-207.

2. Blackwelder, M.J.; Dougal, R.A. Power coordination in a fuel cell-battery hybrid power source using commercial power controller circuits. J. Power Sources 2004, 134, 139-147.

3. Jiang, Z.; Gao, L.; Blackwelder, M.J.; Dougal, R.A. Design and experimental tests of control strategies for active hybrid fuel cell/battery power sources. J. Power Sources 2004, 130, 163-171.

4. Moore, R.M.; Ramaswamy, S.; Cunningham, J.M.; Hauer, K.H. A dynamic simulation tool for the battery-hybrid hydrogen fuel cell vehicle. Fuel Cells 2006, 6, 387-402.

5. Zhao, H.; Burke, A.F. Fuel cell powered vehicles using supercapacitors-device characteristics, control strategies, and simulation results. Fuel Cells 2010, 10, 879-896. 
6. Thounthong, P.; Raël, S.; Davat, B. Energy management of fuel cell/battery/supercapacitor hybrid power source for vehicle applications. J. Power Sources 2009, 193, 376-385.

7. Tang, Y.; Yuan, W.; Pan, M.; Wan, Z. Experimental investigation on the dynamic performance of a hybrid PEM fuel cell/battery system for lightweight electric vehicle application. Appl. Energy 2011, 88, 68-76.

8. Büchi, F.N.; Paganelli, G.; Dietrich, P.; Laurent, D.; Tsukada, A.; Varenne, P.; Delfino, A.; Kötz, R.; Freunberger, S.A.; Magne, P.-A.; et al. Consumption and efficiency of a passenger car with a hydrogen/oxygen PEFC based hybrid electric drivetrain. Fuel Cells 2007, 7, 329-335.

9. Sripakagorn, A.; Limwuthigraijirat, N. Experimental assessment of fuel cell/supercapacitor hybrid system for scooters. Int. J. Hydrog. Energy 2009, 34, 6036-6044.

10. Aso, S.; Kizaki, M.; Nonobe, Y. Development of Fuel Cell Hybrid Vehicles in Toyota. In Proceedings of the Power Conversion Conference (PCC), Nogoya, Japan, 2-5 April 2007; pp. 1606-1611.

11. Bernard, J.; Hofer, M.; Hannesen, U.; Toth, A.; Tsukada, A.; Büchi, F.N.; Dietrich, P. Fuel cell/battery passive hybrid power source for electric powertrains. J. Power Sources 2011, 196, 5867-5872.

12. Keränen, T.M.; Karimäki, H.; Viitakangas, J.; Vallet, J.; Ihonen, J.; Hyötylä, P.; Uusalo, H.; Tingelöf, T. Development of integrated fuel cell hybrid power source for electric forklift. J. Power Sources 2011, 196, 9058-9068.

13. Nishizawa, A.; Kallo, J.; Garrot, O.; Weiss-Ungethüm, J. Fuel cell and Li-ion battery direct hybridization system for aircraft applications. J. Power Sources 2013, 222, 294-300.

(C) 2013 by the authors; licensee MDPI, Basel, Switzerland. This article is an open access article distributed under the terms and conditions of the Creative Commons Attribution license (http://creativecommons.org/licenses/by/3.0/). 